\title{
Anthropometry of the nose: a comparative study between adult male Santhals and Bengalis in Bangladesh
}

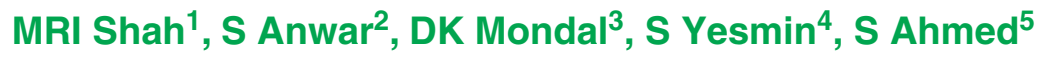

\begin{abstract}
Anthropometry is a scientific methods for taking various measurements of body parts and observation on the living subjects, which play an important role in distinguishing a pure race. The nose is a person's most defining feature because it is at the center of the face. The shape of the nose is a signature indicating the ethnicity, race, age and sex. The aim of this study is to document the mean nasal length, nasal width and nasal index of adult male Santhals and Bengalis in Bangladesh, which provides a comprehensive data for comparisons between each other and with the other ethnic group. Santhals, our study subjects living in the northwest part of Bangladesh, are usually recognized as an ethnic community. Because the Santhals have separate identity and their physical appearance is distinctive to some extent. The study, descriptive, observational and cross sectional is nature, was carried out in the Department of Anatomy, Rangpur Medical College, Rangpur, during the season of July, 2011 to June, 2012. A total number of 100 adult male Santhals and 100 adult male Bengalis were included from different location of Rangur and Dinajpur districts. Nasal length and nasal width were measured using sliding caliper and nasal index was calculated. Unpaired $t$-test was used to compare the measurement. The mean nose length of the Bengalis were significantly higher than the Santhals but the mean of nose width were significantly higher in Santhals than Bengalis. Most of the Santhals were mesorrhine, but most of the Bengalis were leptorrhine.
\end{abstract}

Key words: Anthropometry, nasal height, nasal width, Santhals, Bengalis, Bangladesh.

\section{Introduction}

Anthropometry concern with the measurements of the physical size and shape of the human body. Craniofacial anthropometry is an important technique used in both physical and clinical anthropology. It is very important for the study of human growth and variation in different races and also for clinical diagnosis and treatment. ${ }^{1}$ Several studies have investigated the anthropometric characteristics of the different ethnic groups. $^{2}$

Information is scarce on the anthropometric status of various tribal population and there is no any craniofacial measurement or research data among the Santhals population in Bangladesh. The Santhals are

1. MRI Shah MBBS, MPhil, Assistant Professor of Anatomy, Khulna Medical College, Khulna

2. S Anwar MBBS, MPhil, Professor of Anatomy, Rangpur Medical College, Rangpur

3. DK Mondal MBBS, MPhil, Professor of Anatomy, Gazi Medical College, Khulna

4. S Yesmin MBBS, MPhil, Associate Professor of Anatomy, Rangpur Armi Medical College, Rangpur

5. S Ahmed MBBS, MPhil, Associate Professor of Anatomy, Rangpur Medical College, Rangpur 
known as one of the oldest and largest indigenous communities in the northwestern belt of Bangladesh. They are largely seen in the northern distinct of Dinajpur, Rangpur, Naogon, Thakurgon and Panchagar. ${ }^{3}$ They are the third largest ethnic community in India. ${ }^{4}$

The face of the Santhals are round and softly contoured, the chick bones are moderately prominent, eyes full and straight, nose broad and depressed, mouth large and lips full, hair straight black and coarse. ${ }^{3}$ Their speaking language is Santhals that belongs to Austro-Asiatic subfamily of the Austric family. ${ }^{4}$ Records on cephalometry of Santhals tribal population is very scanty especially measurement like lateral facial profile. Also, there is no comparative study between Santhals and Bengalis. It will be useful and essential tool to the researchers, clinicians and forensic experts in respect to their field of study.

Therefore, the present study attempted to document the nasal anthropometric measurement and nasal indices of the Santhals population and to assess the type of nose and also to assess their nasal measurement in relation to the Bengalis and to determine their status in relation to other population studied elsewhere.

\section{Materials and Method}

The study is a descriptive, observation and cross sectional in nature with some analytical component carried out in the Department of Anatomy, Rangpur Medical College in the season of July, 2011 to June, 2012. The study subjects consisted of a random sample of 100 adult male Santhals and 100 adult male Bengalis, age between 25 to 45 years, residing at different location of Mithapukur and Badarganj of Rangpur District and Parbatipur, Nawabgong and Birampur of Dinajpur districts. Most of them were illiterate so their date of birth was recorded from national identify card. Age was calculated by subtracting the date of birth from the date of data collections. ${ }^{4}$ The history of congenital facial anomaly, major craniofacial trauma, orthodontic treatment, the facial reconstructive surgery that might affect the measurement were excluded from the study.

The measurements were the nasal length (nose height) from nasion (n) to subnasale (sn) and nasal width (nose breath) from alare (al) to alare (al) were measured by physical procedure and the nasal index was calculated as a percentage of nasal width to the nasal length. ${ }^{6}$ The photographs were taken of each subjects for their personal identity and for keeping records. The nose was then classified according to the nasal index and compared to each other and with the other ethnic groups describe elsewhere. ${ }^{6}$

Prosedure of measuring the variables By using sliding caliper, physical measurement were taken at a fixed time between 9 am to $5 \mathrm{pm}$ to eliminate the discrepancies due to diurnal variation. ${ }^{7}$ All the measurements were taken twice to minimize measurement error and were recorded in the data sheet with the help of volunteer. The final value that was used in the study was average of the two obtained value. $^{8}$

After data collection, their frequency distributions, central tendency and dispersions was determined and results were prepared in terms of frequency distribution, ranges, mean and standard deviation using SPSS version 13.0. Unpaired $t$-test was done to compare the mean value with each other and with the other ethnic groups.

\section{Results}

The nose length (mean \pm SD) was significantly higher in Bengalis $(5.0 \pm 0.4)$ than the Santhals $(4.8 \pm 0.4)(p<0.001)$. Both the groups were classified according to the nose length. ${ }^{9}$ The Santhals were in below medium (59\%) followed by above medium $(25 \%)$, but the Bengalis were in above medium (40\%) and large (44\%) (Fig. 1). Again the nose width (mean \pm SD) was significantly higher in the Santhals $(3.8 \pm 0.2)$ than the Bengalis $(3.53 \pm 0.2)(p<0.001)$. According to nose width9, the Santhals were in the above medium (73\%) and large (23\%), 

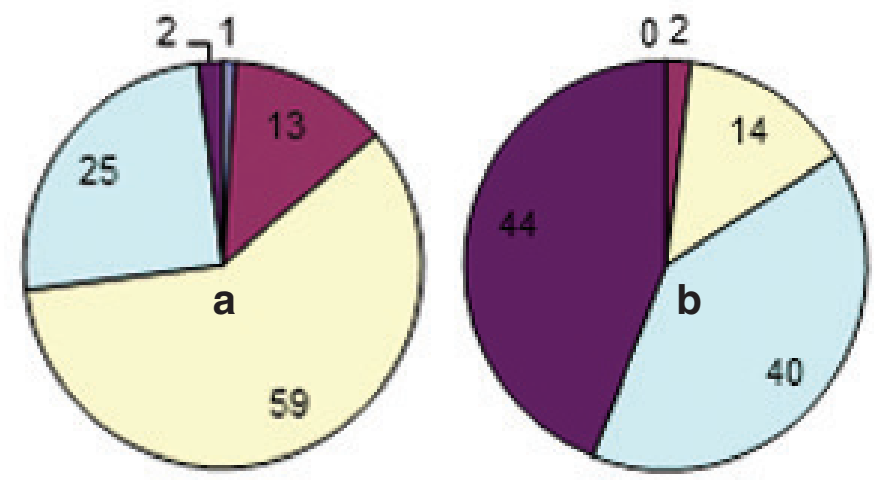

QVeryshort ( $\$ 3.9 \mathrm{~cm})$

aShort $(4.0 \mathrm{~cm}$ to $4.4 \mathrm{~cm})$

QBelow medium ( $4.5 \mathrm{~cm}$ to $4.9 \mathrm{~cm}$ )

口Above medium ( $5.0 \mathrm{om}$ to $5.4 \mathrm{on})$

aLgrge $(25.5 \mathrm{~cm})$

Fig. 1. Pie diagram showing percentage frequencies of different types of nasal length. The values within parentheses represent nose length in the a) Santhals and b) Bengalis.

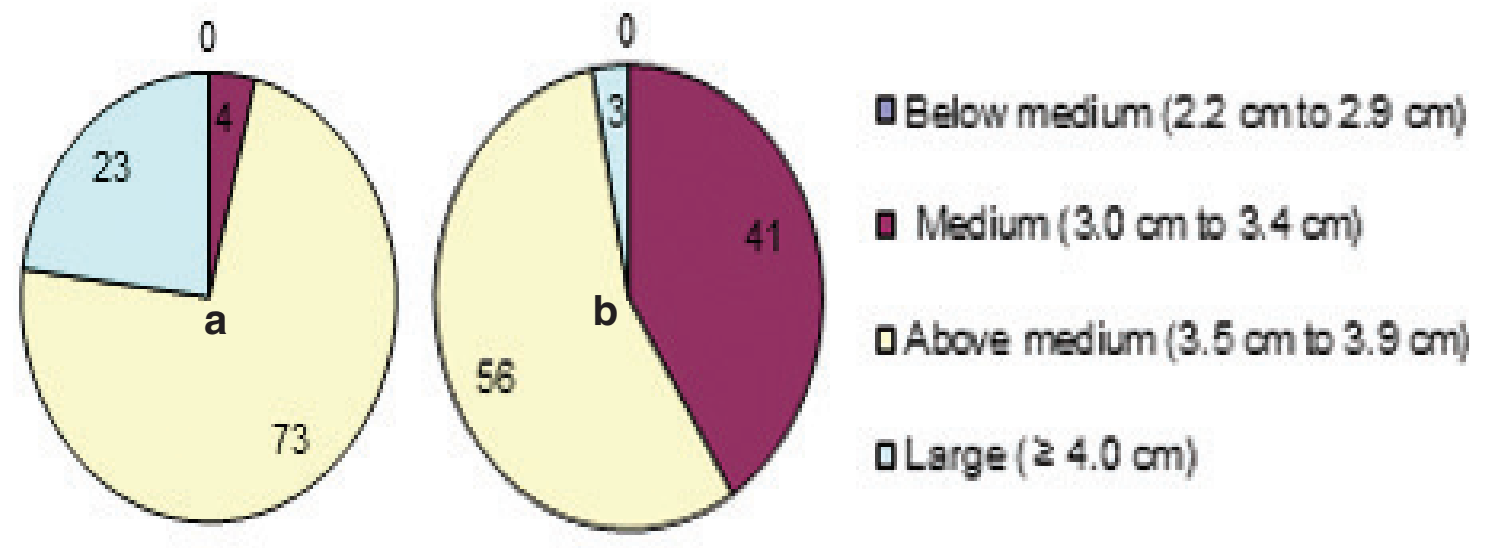

Fig. 2. Pie diagram showing percentage frequencies of different types of nose width. The values within parentheses represent nose width in the a) Santhals and b) Bengalis.

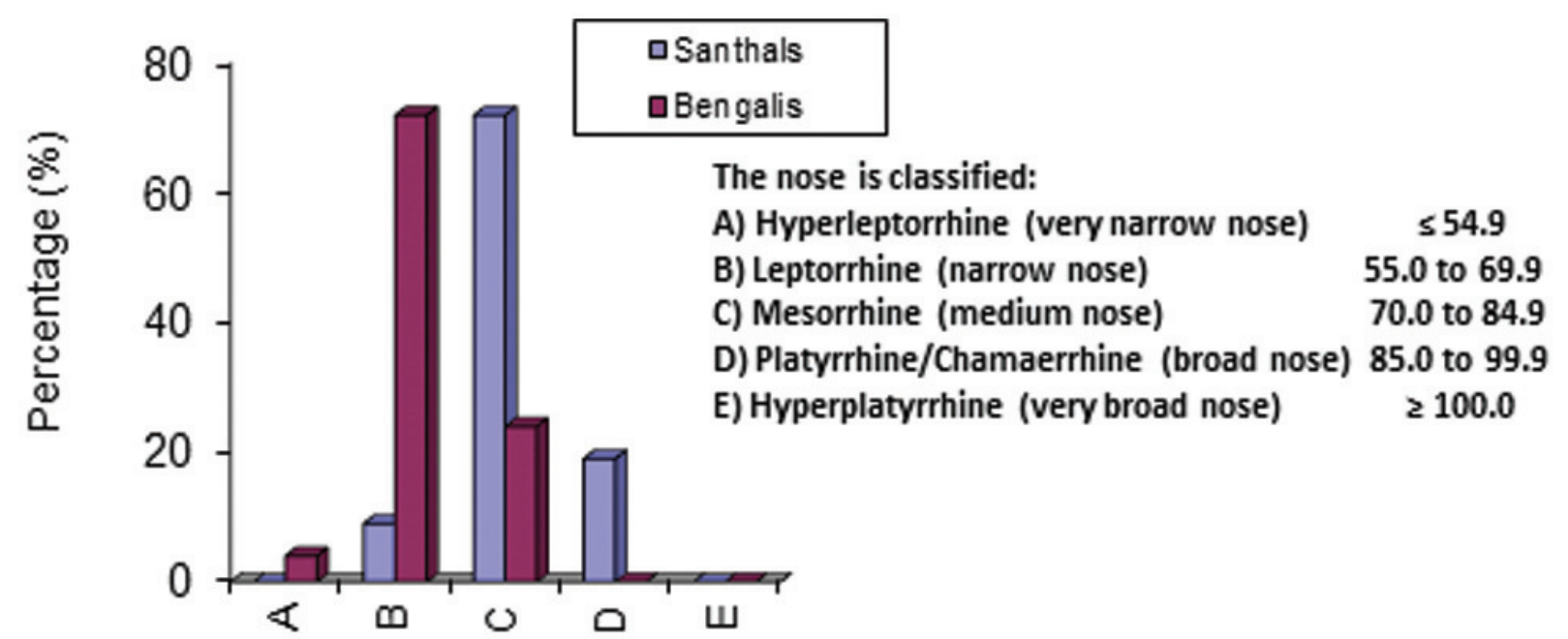

Fig. 3. Distribution of subjects by nasal Index. 
Table 1. Distribution of the subjects by nasal measurements

\begin{tabular}{lccc}
\hline \multicolumn{1}{c}{ Variables } & \multicolumn{2}{c}{ Subjects } & p value \\
\cline { 2 - 3 } & $\begin{array}{c}\text { Santhals } \\
(\mathbf{n = 1 0 0})\end{array}$ & $\begin{array}{c}\text { Bengalis } \\
(\mathbf{n}=\mathbf{1 0 0})\end{array}$ & \\
\hline Nose length (n-sn) $(\mathrm{cm})$ & $4.8 \pm 0.4(4.0-5.8)$ & $5.4 \pm 0.4(4.2-6.2)$ & $<0.001^{*}$ \\
Nose width (al-al) $(\mathrm{cm})$ & $3.8 \pm 0.2(3.3-4.3)$ & $3.5 \pm 0.2(3.0-4.1)$ & $<0.001^{*}$ \\
Nasal index & $80.0 \pm 7.2(53.4-83.3)$ & $65.9 \pm 6.3(63.0-97.6)$ & $<0.001^{*}$ \\
\hline
\end{tabular}

Data are shown as mean \pm SD (range). ${ }^{*}$ : Significance by unpaired $t$-test.

but the Bengalis were in the medium (41\%) and above medium (56\%) (Fig. 2).

The nasal index (mean \pm SD) of the Santhals $(80.0 \pm 7.2)$ was higher than the Bengalis $(65.9 \pm 6.3)$ (Table 1). There was significant difference between the Santhals and the Bengalis $(p<0.001)$. Both the groups were classified according to the nasal index. ${ }^{9}$ Most of the Santhals belonged to the mesorrhine $(72 \%)$, but the Bengalis were mostly in the leptorrhine (72\%) (Fig. 3).

\section{Discussion}

The findings of the present study regarding the nasal variable were compared between Santhals and Bengalis and with the finding of various author studied on various ethnic groups. The Santhals are proto-Australoid on the basis of anthropological origin, but the Bengalis are Australoid type., ${ }^{2,5}$ The mean nose length of the Santhals was lower than the Bengalis and according to nose length the Santhals were mostly in the below medium group (59\%). The similar below medium nose was found in Rai of Nepal, Limbu of Nepal, Indian male, Santhals of West Bengal, Tonga, Lufa of New Guinea, Angolan. $4,14,17,18$ Therefore, this report supports to Bhasin, who described the Australoid as below medium nose are the inhabitance of South and Central India, Srilanka and Malay Peninsula. ${ }^{2}$ The Bengalis were all most equally distributed in large type (44\%) and above medium (40\%).

On the other hand, the mean nose width of the Santhals was higher than the Bengalis. According to nose width the Santhals were above medium (73\%), followed by large type $(23 \%)$, the Bengalis were also in above
$(23 \%)$, the Bengalis were also in above medium type. Similar above medium type of nose width was found in Onges, Rai of Nepal, Limbu of Nepal, Indian male Santhals of West Bengal, Russiun, Malaysian Indian, Polish, Caucasian, Singaporean Chinis, Bulgarian and Chack. 4,8,9,17,18

Majorly of the Santhals were mesorrhine or medium nose (72\%) followed by chamarrhine or broad nose (19\%), whereas the Bengalis were leptorrhine or narrow nose $(72 \%)$ followed by mesorrhine or medium nose (24\%). Similar mesorrhine nose was found in Shindhi of India, Malaysian Indian, Andhoni, Karkar of New Guinea and Santhals of West Bengal. ${ }^{1,4,8,13,14}$ During maturity and old age, a natural increment in the cartilaginous tissue of the face can be observed, giving people longer and larger nose. ${ }^{10}$ Gosh and Malik reported that the Santhals of West Bengal, India were mesorrhine, these report supports Ngeow who reported that the Indian males were mesorrhine, whereas the north American white Caucasian were letorrhine..$^{4,8}$ These also supports to Bhasin who described that caucasoid are mesorrhine to letorrhine. $^{2} \quad$ Anthropological studies suggested that the shape of the nose can be influenced by environmental climatic condition. Large nasal index indicates broad nose associated with hot and moist climate and small nasal index indicates narrow nose associated with cool and dry condition. ${ }^{8}$ As the climate of Bangladesh is hot, large nasal index help the Santhals to adopt and survive efficiently in hot climatic condition of their surroundings. 


\section{Conclusion}

The study showed that the adult male Santhals of Bangladesh are mostly mesorrhine or medium nose followed by chamarrhine or broad nose, but most of the Bengalis are leptorrhine or narrow nose followed by mesorrhine or medium nose. The study may be useful and essential to the researchers, clinicians, anatomist, anthropologist, nutritionist and forensic experts in respect to their field of study. The data may also provide as the basic framework for estimating the standard of the nasofacial dimensions.

\section{References}

1. Oladipo GS, Eroje MA, Fahwehinmi HB. Anthropometric comparison of nasal indices between Andoni and Okrika tribes of Rivers state, Nigeria. Int J Med Med Sci 2009;1(4):135-7.

2. Bhasin MK. Genetics of castes and tribes of India: Indian population milieu. Int J Hum Genet 2006;6(3):233-74.

3. The Bangladesh News, 27 March. http://www.independent-bangladesh.com /ethnic-groups/the-chakma.html. (Accessed on March 12, 2015).

4. Ghosh S, Malik SL. Sex differences in body size and shape among Santhals of West Bengal. Anthropologist 2007; 9(2):143-9.

5. Wikipedia, the free encyclopedia, Santals. http://en.wikipedia.org/wiki/ Santals. (Accessed on March 12, 2015).

6. Soames RW. Skeletal system. In: Williams PL, Bannister LH, Berry MM, et al. (eds.), Gray's Anatomy, 38th eds. Churchill Livingstone, UK, 1995.

7. Shah GV, Jadhav HR. The study of cephalic index in students of Gujarat. Journal of the Anatomical Society of India 2004;53(1):25-6.

8. Ngeow WC, Aljunid ST. Craniofacial anthropometric norms of Malaysian Indians. Indian Journal of Dental Research 2009;20(3):313-9.
9. Pandey AK. Cephalo-facial variation among Onges. Anthropologist 2006;8(4):245-9.

10. Joy O, Ahmed E, Oladipo G, Ezon-ebidor E. Anthropometric study of the facial and nasal length of adult Igbo Ethnic Group in Nigeria. The Internet Journal of Biological Anthropology 2009;2(2), ISSN: 1939-4594.

11. Salve VM, Thota NR, Patibandla A. The study of cephalic index of Andhra Region (India). Asian J Med Sci 2011;2:53-5.

12. Oladipo GS, Esomonu C, Osogba IG. Craniofacial Dimensions of ljaw Children and Adolescents in Nigeria. Biomedicine International 2010;1:25-9.

13. Chowdury A, Chowdury DS. Comparative anthropometric study of nasal parameters between two ethnic groups of Rajasthan State. Int J Med Public health 2012;2(2):46-8.

14. Harvey RG. An anthropometric survey of growth and physique of the populations of Karkar Island and Lufa subdistrict, New Guinea. Phil Trans R Soc London 1974;268:270-92.

15. Nagle E, Teibe U, Kapoka D. Craniofacial anthropometry in a group of healthy Latvian residents. Acta Medica Lituanica 2005;12(1):47-53.

16. Ngeow WC, Aljunid ST. Craniofacial anthropometric norms of Malays. Singapore Med J 2009;50(5):525-8.

17. Farkas LG, Posnick JC, Hreczko TM. International anthropometric study of facial morphology in various ethnic groups/races. Journal of Craniofacial Surgery 2005;16(4):615-46.

18. Shrestha O, Bhattacharya S, Jha N, et al. Craniofacial anthropometric measurements among Rai and Limbu community of Sunsari district, Nepal. Nepal Med Coll J 2009;11(3):183-5.

19. Umar MBT, Ojo AS, Asala SA, Hambolu JO. Comparison of Cephalometric Indices between the Hausa and Yoruba Ethnic Groups of Nigeria. Research J Med Sci 2011;5(2):83-9.

\section{Suggestion for citation of the above:}

Shah MRI, Anwar S, Mondal DK, Yesmin S, Ahmed S. Anthropometry of the nose: a comparative study between adult male Santhals and Bengalis in Bangladesh. Mediscope 2015;2(2):28-32. 